Peter V. Dobrolyubov

Vice-President of the Tchertkoff Memorial \& Cultural Fundation (TCMCF inc.), Academician of Fine Arts, Member of the Creative Union of artists,

Member of the Moscow Union of artists,

Member of the Union of artists of Russia,

Association of Moscow sculptors

e-mail: peterdobrolioubov@gmail.com

Moscow, Russia

ORCID 0000-0003-0709-3265

DOI: 10.36340/2071-6818-2020-16-4-113-132

\title{
PAINTING AS A PRAYER OF THE SPIRIT
}

Summary: The article is devoted to the work of the Russian painter Dobrolyubov Vladimir Petrovich, who in 2020 marks the centenary of his birth. Special attention is paid to the presentation of his ideals, which inspired the artist to create wonderful paintings depicting the world around him, landscapes and landscapes, urban environment, monuments of ancient Russian architecture, decoration and interiors of the oldest churches from Moscow to Yaroslavl, Pereslavl Zalessky, Staraya Ladoga. From the Russian North to the Crimean mountains and Tsemeskiy Bay.

Vladimir Petrovich Dobrolyubov (05.07.1920-24.02.1975) - a student of I.I. Mashkov, N.P. Krymov, G.G. Ryazhskiy, K.F. Yuon, V.V. Krainev, P.I. Kotov, V.I. Finogeev, K.G. Dorokchov.

Dobrolyubov V.P., was the veteran of the Great Patriotic war (1941-1945), - the 75th anniversary of the Victory which we celebrate this 2020 year.

The author analyzes the paintings of V.P. Dobrolyubov - a natural colorist, nugget, artist, philosopher and citizen of his country. His thoughts on the art of painting based on the beauty and traditions of the Russian school of iconography were the Foundation, the spiritual platform, for all of his painting, created in a short period of life.

The author's paintings Dobrolyubov V.P. is of well-deserved interest for art studies and make a worthy, significant contribution to it not only by their high appreciation of color, color spot, and lyrical appearance, but also as works of the history of Russian painting and in particular, the Moscow school of painting, 30-60-ies of XX century, of which he was a representative. Also noteworthy is his understanding of art, his creative pictorial, original, author's handwriting, and also an amazing vision of color and color spot, his own, individual. As well as the interpretation of personal perception, the attitude and understanding of the fundamental foundations of realism in the domestic and world fine arts, expressed and approved in their own, no one repeats, coloristic pictorial language.

Dobrolyubov V.P. considered icons, the Russian icon, as a work of art, which following the tradition of Byzantine masters of iconography, undoubtedly constitutes the core of the soul of the artistic creative process, and espe-

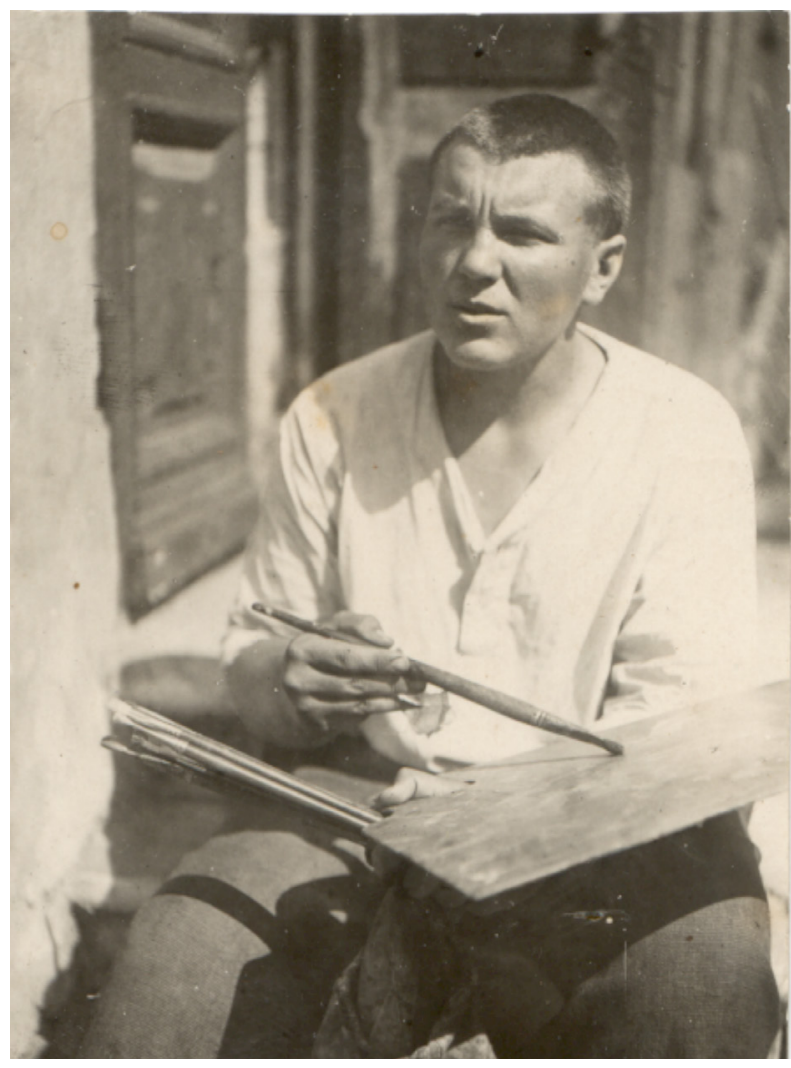

V.P. Dobrolyubov at molbert. Red Army. 1940

cially the work of iconographers such as Andrei Rublev, Theophanes the Greek, Vladimir-Suzdal, Moscow, Yaroslavl school of icon-painting as an objective reality of the world of spiritual images in their own work.

Artistic creativity, in his opinion, as a representative of the Moscow school of painting, is not an abstract search and self-expression of the artist's beliefs and ideas, but the result of a deep, divine transformation of the soul, its path to truth and to the foundations of realistic art, through the perception of artistic images.

Russian iconography of the XIV-XVII centuries, brought to Russia from Byzantium, Dobrolyubov V. P. considered the 
Russian school of iconography the main, unsurpassed, imperishable Foundation and a masterpiece of Russian fine art.

Everywhere in his memories, in his understanding of the basics of art, the artist renounces the concept of copying the image and the icon for him is like a conditional historical symbol, indicating the spiritual image of past centuries. An artistic image is born in the soul of the painter and of course exists outside of iconography, but then it can appear in the minds of other people who contemplate the master's canvases, in which the image of the universal universe and the beauty of the universe is encoded, if you want, encrypted in the very deep images of Russian iconography. Therefore, the icon itself, its image and composition, as a work of art created once in the depths of past centuries, is personified in the mind of the author, as grace and inspiration sent from heaven.

Dobrolyubov V.P. confirms the aesthetic and spiritual platform created for any person. Therefore, Russian icons created as spiritually and artistically perfect, selfsufficient works of Russian culture are inextricably linked to the General process for Russian art history, its ability to testify to its highest level in the hierarchy of world art.

For the artist Dobrolyubov, Russian iconography is an inseparable part of his spiritual platform, and his works of painting - and, temple art, in conjunction with ancient Russian architecture, with the interiors of churches and their decoration, as well as the sacrament of divine services, baptisms, weddings and funerals, and are the most essential foundation, being, as the very artistic image of all his art work and now, in 2020. Today, 45 years after his death in 1975, his artistic paintings are just as beautiful and heartfelt.

Keywords: Russian and Soviet fine art of the XIX-XX centuries, ancient Russian icon, Byzantine iconography, Moscow school of painting, visual art object, artistic image, fine art, symbol, realism

"In art the Earth imitates the Sky".

A. Block ${ }^{1}$

The year 2020 marks the century of the birth of the remarkable Moscow artist, landscapist Vladimir Petrovich Dobrolyubov (05.07.1920-24.02.1975), a student of titans of art as I.I. Mashkov, N.P. Krymov, G.G. Ryazhsky, K.F. Yuon, V.V. Krainev, P.I. Kotov, V.I. Finogeev, K.G. Dorokhov. Dobrolyubov V.P., was a veteran of the great Patriotic war, - the $75^{\text {th }}$ anniversary of the Victory of which we are celebrating this year.

Dobrolyubov V.P. was born in Moscow, on June $24^{\text {th }}$, old style, at 12 o'clock in the morning, new style on July $5^{\text {th }}, 1920$ on Yabloniy lane, 22/1, in the family of an officer of the Leib Guards of the Saint Petersburg King Friedrich Wilhelm III regiment-Dobrolyubov Pyotr Grigoryevich and his wife Dobrolyubova (Moroznikova) Alexandra Pavlovna.

The flourishing of fine art is a symbol of the flourishing culture of the people in any country. In a decaying country where historical monuments of past centuries are being demolished and forgotten, the flourishing and culture of this people will be forgotten as well.

Sometimes art becomes just an abstract luxury for a select few. When a country is in full spiritual strength, then art itself becomes a true cultural soil, a basis, an intellectual Foundation for its people, which feeds them with the juices of the land of their fatherland, which is inextricably linked with the history of art created by past generations of distant, previous epochs.

1. A.Blok. Diary. M., 1989. p. 50.
Imagine the history of mankind without these treasures of great art and its unsurpassed beauty and amazing harmony. We will find that whole epochs will remain without any meaning, devoid of the soul and grandeur of art. Without revealing spiritual beauty, we will remain in the midst of the ugliness of devastating ignorance and ignorance. When we say that beauty, art, creativity is life, we are talking about the future life for people. Everything that is done for true creativity, for art, is already a feat of man, a creator. So highly appreciated the role of art and the artist himself in his work. He believed that art brings people to understanding the essence of things, to understand the true beauty and goodness, the greatness of the universe and, therefore, the life of all mankind the value of art, artists who create it, is invaluable.

V.P. Dobrolyubov saw the deep meaning of art in the fact that it is art that is given to support the spiritual essence of any person and help him in the days of adversity and the most difficult trials to rise from his knees. The power of knowledge and the depth of art are not the luxury of a narrow group of people. The knowledge of the universe and the creation of art is the feat of a human artist, whether a painter, sculptor or architect. It is a prayer to art and a feat of the spirit that show the world authentic artistic masterpieces of different epochs and peoples. Since this is a prayer to art, the power of the spirit of the Creator of the work is most necessary when the artist stands alone with himself at 


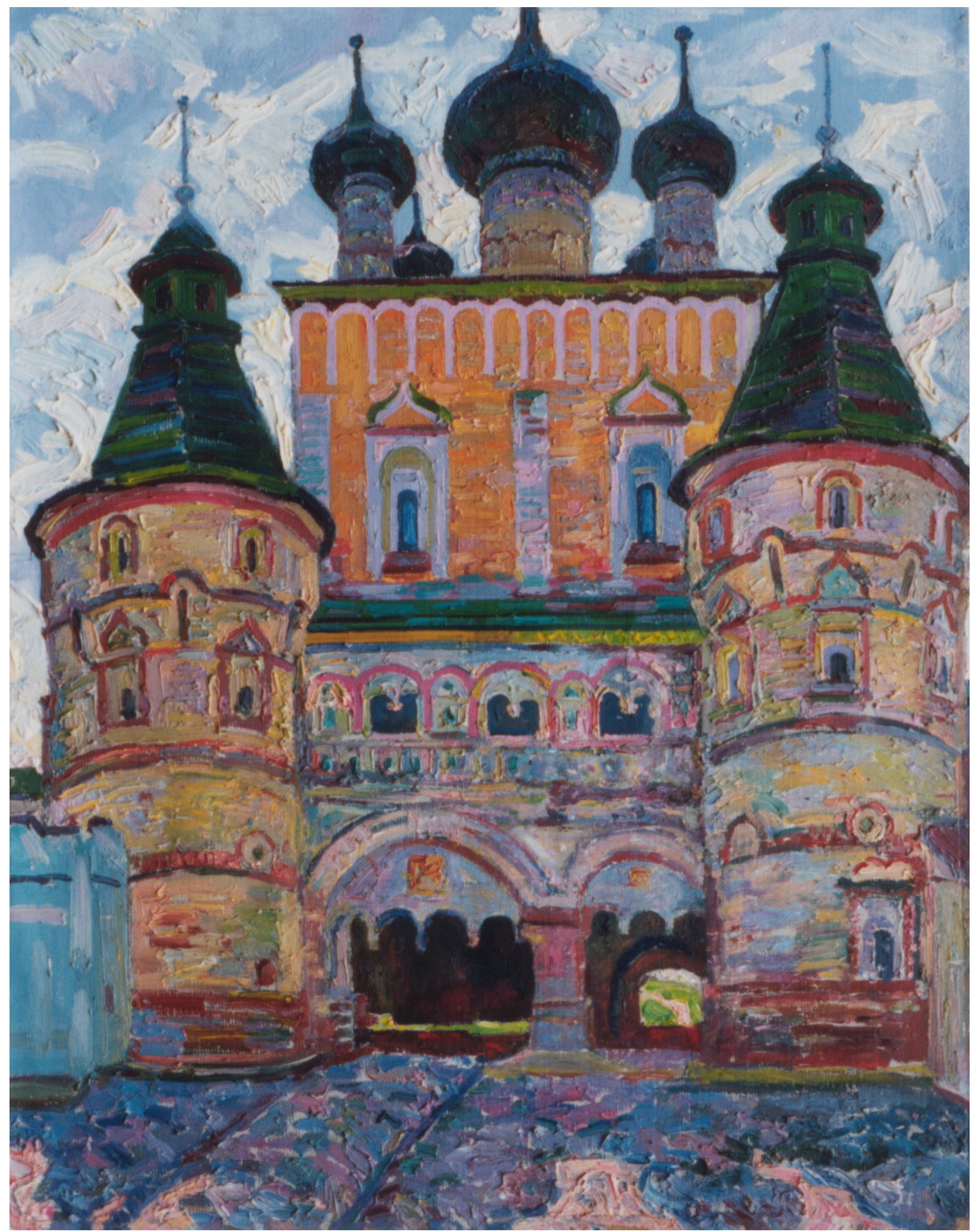

Borisoglebsk. 1968

the canvas and easel, as an earthly being, inspired by the divine power of the world around us, and therefore needs a firm support. The artist himself should always look for a wise solution.

And where the spiritual and earthly support is firmer, only there will the spirit of creation be kindled with extraordinary penetration. The artist repeats again and again: creativity as a comprehensive substance is a crystal-clear prayer of the spirit. And true art is the heart of any nation and any ethnic group.

The knowledge of the surrounding world, the divine primordial nature, is the people's mind. Only exclusively with their kind, peaceful heart and innate 


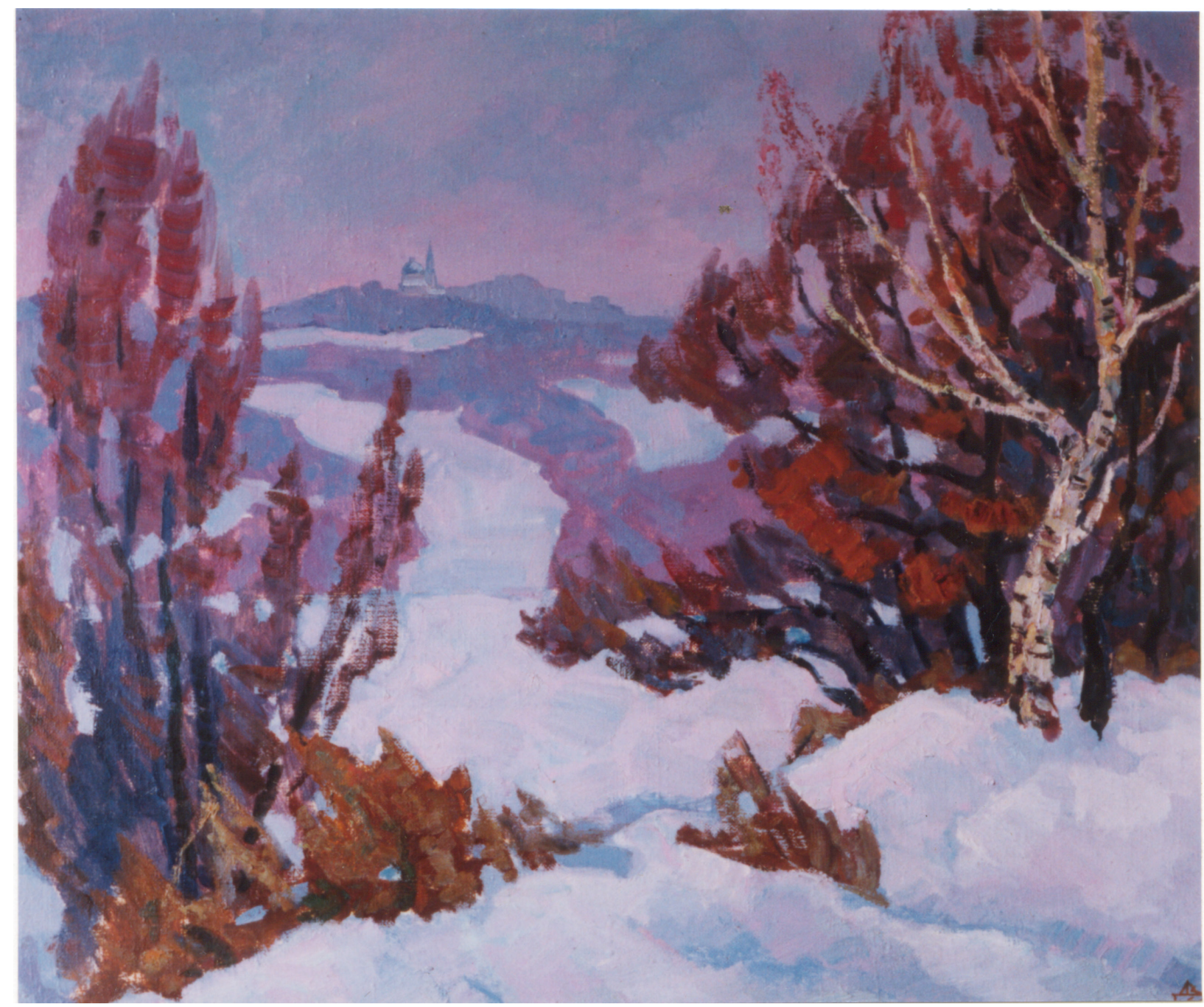

PeresIsvl Zalesskiy. 1967

wisdom can the peoples of this world unite and understand each other and meet each other halfway. And if this is not the case, then the entire human race goes wild.

Dobrolyubov V.P. did not hesitate to study throughout his life. Outstanding artists such as,- I.I. Mashkov, N.P. Krymov, G.G. Ryazhskiy, K.F. Yuon, V.V. Krainev, P.I. Kotov, V.I. Finogeev, K.G. Dorokchov,- teachers of the artist V.P. Dobrolyubov were all talented teachers by vocation. All their multi-faceted painting activities was also pedagogical. They are educators, mentors, and sensitive educators. Purposeful, passionate in art and persistent in educating our youth.

From 1937 to 1940, he studied at the art school named after "Memory of 1905"; in 1940-1947, he served in the Red Army. The artist participated in the fighting with nazi Germany and military Japan in the rank of senior Sergeant, and was awarded the medals "For the victory over Germany", "For the Victory over Japan" and other medals. In 1946, Dobrolyubov V.P. was accepted to the Grekov atr studio on a competitive basis with artists N. Zhukov and V.B Utenin.
The creative heritage of the painter Dobrolyubov V.P., whether it is diary pages, author's paintings, stories, poems, is an inspired call to comprehend art, to cultural construction. The depth and breadth of knowledge combined with life and creative experience gave the artist invaluable material for many paintings. In 1953, he made his debut in an exhibition of artists with the oil art work "A.M. Gorkiy on the seashore " (1953). From 1954 to 1960, he has creative work in the Crimea, Gurzuf in the house of creativity named after K. Korovin and in Sudak. Here are just some of the canvases: "Sudak, evening" (1954), "Gurzuf" (1955), "Yalta" (1956), " House of creativity K. Korovina" (1956), "Autumn in the Crimea" (1957), "At the Bear mountain "(1957)," Crimea, Red Stone " (1958). "Gurzuf bay "(1959), "Warm evening "(1960)," Sudak "(1960)," Sea in the evening "(1960)," Crimea (1960), Cypresses" (1961). Only a small part of his works are presented in our magazine.

Different in depth, subject, scope, genre, and volume, they are all imbued with a common idea: without art, human life is absolutely impossible, devoid 


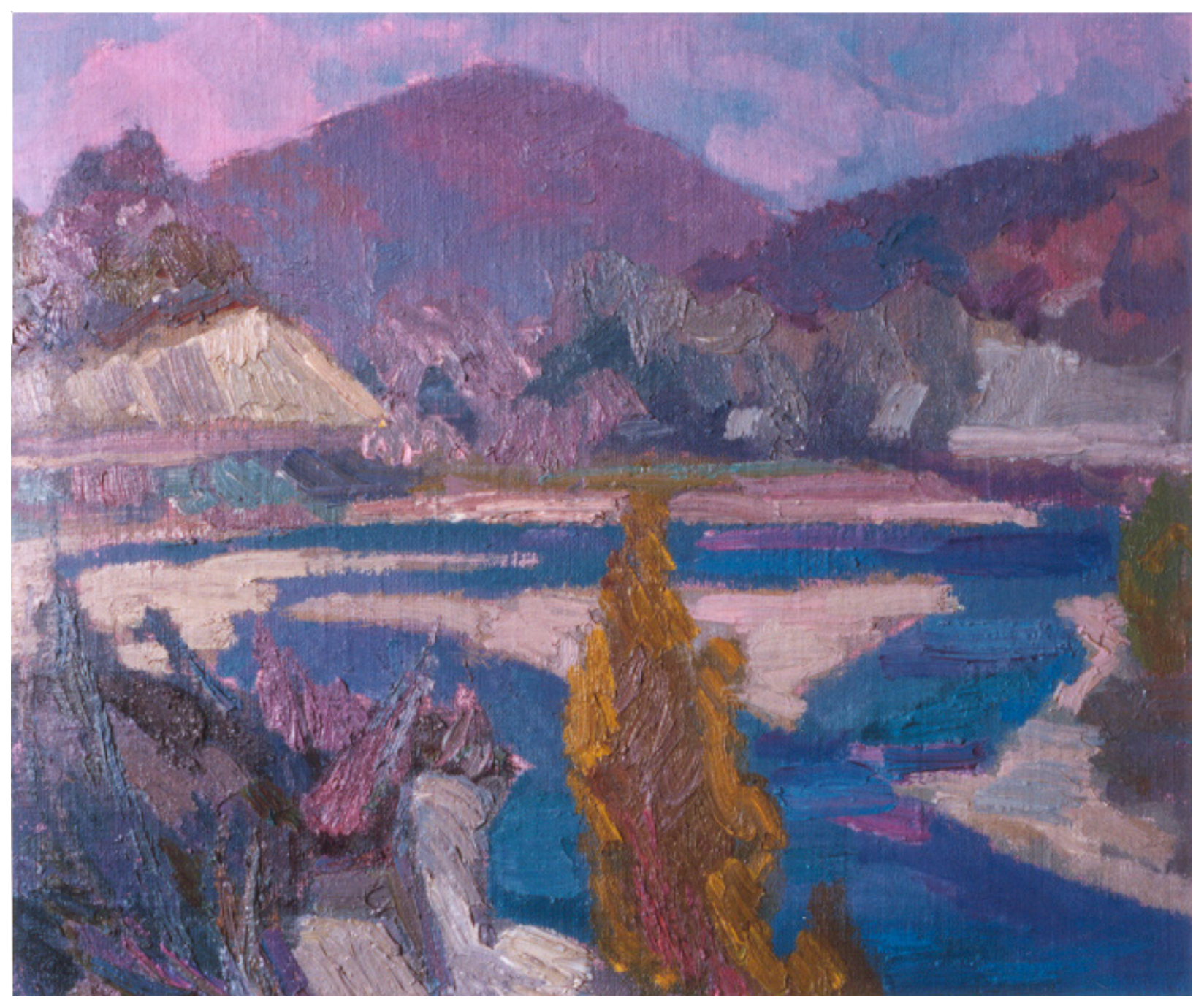

Goriatchiy Klutch. 1971

of any meaning and beauty. Sometimes the artist touches on seemingly narrow professional issues: composition, tone in painting, landscape or still life, methods of working on the work, chemical composition of paints, etc. However, all of them are extremely important, because they show the essence of the creative activity of V. p. Dobrolyubov, as an artist, thinker, and citizen of his homeland.

Dobrolyubov's paintings deeply and joyfully reveal his attitude to the artist's work, to the laws and nature of creation in the creative process. A person who does not know the past, the artist argued, cannot think about the future. That is why Dobrolyubov V.P. himself devoted his work to subjects with ancient Russian architecture, icons, frescoes, mosaics in the interiors of mighty giants of temples, which convey on canvas it's wonderful, heavenly, lightbearing colors. At last we saw the light: from our temporarily forgotten storerooms, we got another wonderful and wonderful treasure.

The knowledge of icons will be a true talisman on the way to our other ancient treasures and beau- ties, so close to the search for the future life. And all the work of the painter Dobrolyubov V.P. is a living and very convincing proof that ancient Russian art is not just a beautiful Museum exhibit, or an obsolete form of artistic creativity, but the divine universe itself, surrounding all of us, all of humanity. The artist himself, realizing the deep meaning of icon painting, was able to see the main thing in ancient Russian art, and in his own way continued its traditions in his art.

In 1963, Dobrolyubov V.P. wrote one of his best canvases "Verchniya Maslovka. View from the window " (1963). This is not even just a still life, but a unique epochal canvas in form, skill and beauty-a picture that combines scientific authenticity with the insight of a clairvoyant. It takes your breath away when you travel through time with the author and finally find yourself in the depths of the "Artist's Town" on Verkhnyiya Maslovka. The artist seeks a single root of his creativity in unity with the world art of painting and finds it in unsurpassed masterpieces of the past. 


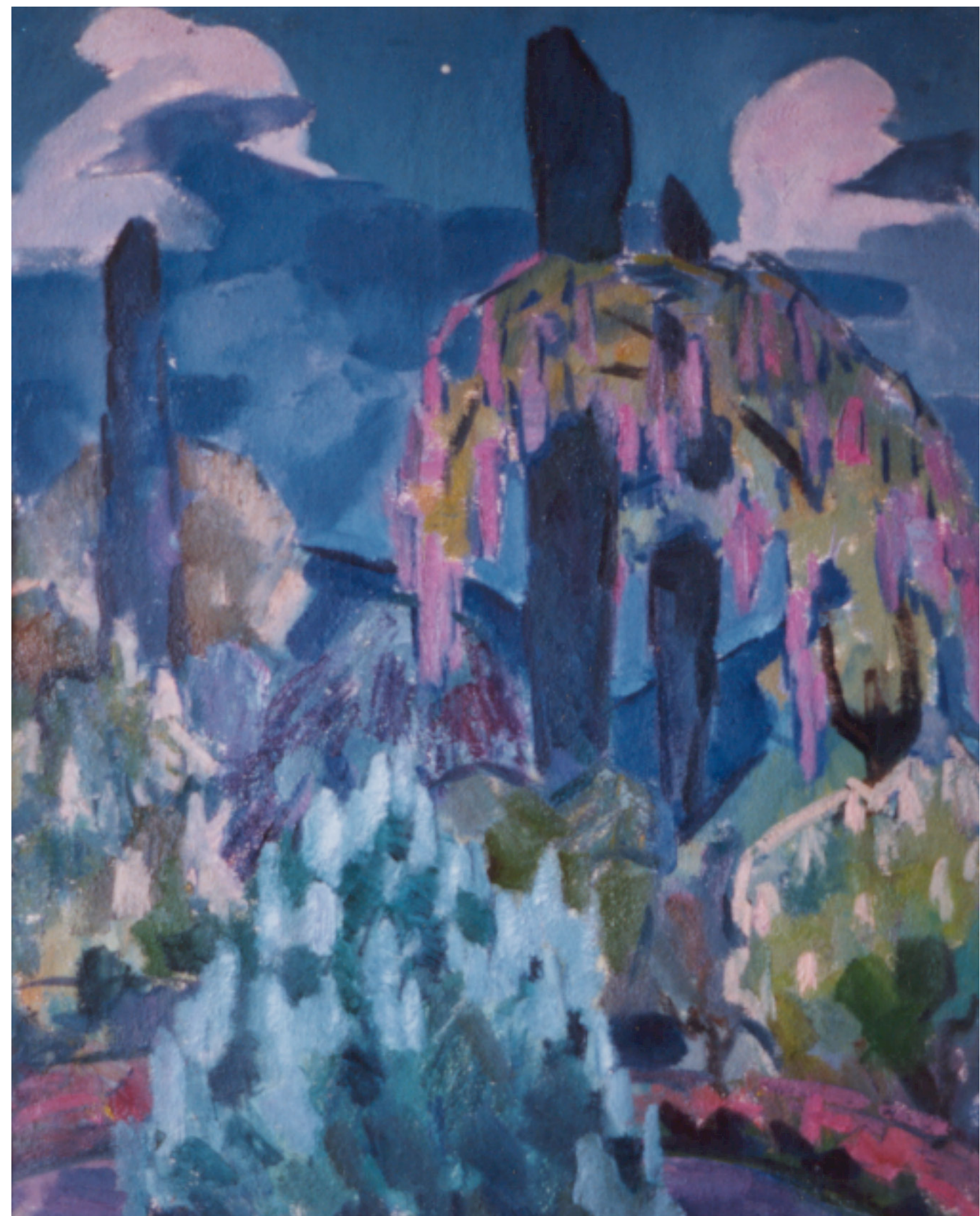

Gourzuf. 1956

Since 1964, the artist has been working in the house of Creativity in Tarusa. His canvases are full of lyricism and charm of native nature, such as "the Stars lit up "(1964)," Evening at the Oka river "(1964)," Tarusa "(1964)," Sunset " (1964). In 1968, the artist was accepted into the painting section of the USSR Union of artists of the Moscow organization. In 1969, the artist participated in the exhibition "Monuments of history and culture of our Motherland in the works of Moscow artists" MOSH RSFSR such works as" Suzdal "(1965), " St. Nicholas wooden Church from the village of Glotova."(1966), "Interior of the Church of the Resurrection in Rostov-Velikiy "(1967)," Autumn in Rostov "(1967), " Western facade of the Church 
of the Intercession on the Nerl river. Dawn "(1968)," the Temple of Boris and Gleb in Kideksha "(1968), " Spring evening. Church of the Ascension in Kolomenskoye" (1968).

It is a shame for our time that in ancient times there was not a single object of everyday life without the true work of the author, man, master, artist. It is impossible even to compare the popular usage of our modern life with the fact that generations of their predecessors from the same places so persistently sought to have around them. Attach an idea, your knowledge, your experience, palette and brushes to any beautiful things, and it will not disturb the overall impression of his painting. It will bring with it a note of creativity and peace, depth of knowledge of the world around us and the nobility of the creative process itself.

Delving into the centuries, Dobrolyubov V.P. outlines the main milestones of joy in the creation of his painting art. The main theme is Russian art, which has always delighted the master with its uniqueness, imagery and vitality. Everything that came to Russian art from outside, dissolved, became organic only when it corresponded to the spirit, character, views, habits of the people, their national characteristics.

Our native Russian culture has never shied away from the culture of neighboring and even distant countries, but it has always remained true to its historical fundamental traditions. A poet of art, historian, philosopher, artist and art critic, Dobrolyubov V.P. considered art in the unity and laconism of all known genres, in the General artistic way throughout his earthly creative life.

His landscapes are a song about the beauty of the Russian land, its charm, which for the artist Dobrolyubov V.P. is included in his paintings quite a tangible phenomenon. Many of these landscapes were transferred to his canvases. Let's remember just a few - "Staraya Ladoga. North" (1969), "'Truvorov cross "(1970), " Yuriev Polskoiy "(1970), " At dawn "(1970), "Heavenly call" (1970).

Since 1969, he has been fruitfully created canvases with the unspoilt nature of the village "Soviet Artist" in Peski and its surroundings. The nature there is still amazing, the same blue sky waves of the Moscow river, cherry clouds above it, the same abysses of acacias, peonies, tulips in the gardens of neighboring artists. The author can create only when his heart is given to people and his soul is open to live impressions, the beauty of the universe. Here are some canvases of this period "Golden autumn "in 1972," Apple blossoms "(1972)," still Life with a book "(1973)," Konev Bor "(1973)," Apple trees in the garden "(1974)," Night, sands " (1974), and many others. Speaking bitterly about the degradation of contemporary art abroad, the loss of national traditions, the artist expressed no less concern about the decline of artistic culture in Russia, the aesthetic needs of the people.

Dobrolyubov V.P. from childhood was imbued with a love of decorative and applied art, understanding its huge possibilities. it is not for nothing that for many years he painted his still-lifes with folk crafts. This is the subject of his fundamental canvas "Carousel", the carousel depicts the images of folk crafts that he loves so much. As an artist who has worked in many of Alexander Roy's films, he objected to the unfair separation of the so-called "art industry" from art and the relegation to something secondary.

He believed that there are no secondary areas of application of creative forces-there are bad artists. A great master creates a high work of art from any material and by any technical means-repeated V.P. Dobrolyubov, following his constant motto: "Art is one".

Of course, the moral image and behavior of the Artist-Creator in society directly affect the results of his activities.

A part of his memoirs is devoted to the relationship between "young" and "old" artists in the "Town of Artists" on Verkhnyiya Maslovka, where he lived. There he continues the theme of the artist's ethics, "artistic people of different faiths" and expresses his firm belief in the need to unite all the creative forces of the country in the comprehensive cultural construction.

In 1969-1970 he fulfilled a creative art trip to Staraya Ladoga took place, where a large number of his canvases were created. Work in the house of creativity and participation in the reporting exhibition of the house of Creativity of the USSR.

1970 MOSH RSFSR awards Dobrolyubov V.P. diploma for participation in the $5^{\text {th }}$ exhibition of works by artists-veterans of the Great Patriotic war, dedicated to the $25^{\text {th }}$ anniversary of the victory over Nazi Germany.

Centuries of experience show us that art and knowledge flourished where they were recognized from above as the greatest stimuli of life. Where the heads of state, where the lords of the church and all the leaders of life converged in the pursuit of beauty, only there was the renaissance, the renaissance that our art historians now write such delightful books about - - said the artist, continuing the same theme 

about all types of art and architecture without which the human personality is deprived of the prospects of its true development and movement forward to the heights of world knowledge.

Dobrolyubov V.P. was a convinced realist-romantic, because he considered the highest task of art to display life as such, in all its depth and versatility. "True realism reflects the essence of things. For true creativity, realism is the initial ascent. How many times has the most real piece of nature been called the nevernever? Not to mention the colors. These combinations of color palettes, quickly, a la prima and sketchily taken from nature, were declared impossible, and the forms captured from nature were considered for some reason an invention.

A deeply realistic approach to the depicted plot is the main feature of V.P. Dobrolyubov's work, which combines a bright author's identity with vital authenticity. It is not surprising, therefore, that the use of his cavases "At the Savino-Storozhevskiy convent" (1961), "Morning in Pereslavl-Zalesskiy "(1963) served the cinema director A. Roy to create his magical children's films at the Gorkiy youth film Studio, such as "Fire, water and copper pipes " (1967), where Alexander Roy himself persuaded the artist V.P. Dobrolyubov personally to play the role of the Royal cupbearer in this cinema picture.

The artist believed that all of us are able to see the beauty of the world around us, created by the heavenly forces. This is the mysterious "heavenly architecture" So picturesque

The artist believed that all of us are able to see the beauty of the world around us, created by the heavenly forces. This is the mysterious "Heavenly Architecture" as the artist called the clouds, which always brought him great aesthetic joy. He wrote: all people are definitely divided into two types. Some know how to enjoy the heavenly architecture, but for others it is silent, or rather, their hearts are silent and silent. And only children are able to enjoy the clouds completely and raise their imagination at a young age. But our imagination is only the result of observation. And everyone from the first days of it is already offered an indescribable beauty of its heavenly painting. People should love the beauty in the world around them, and this love should be constantly developed. So Vladimir Petrovich Dobrolyubov thought.

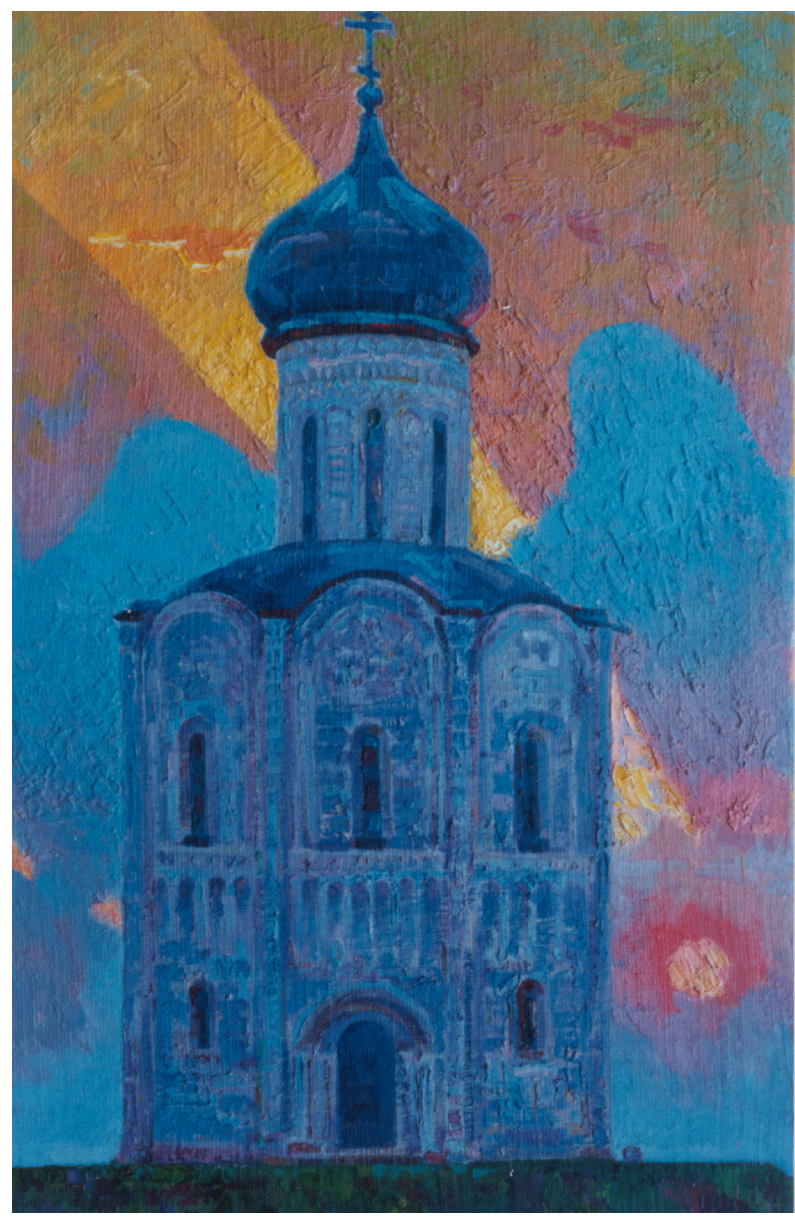

Pokrova on Nerl. 1965

From 1971 to 1975, the artist often works In the house of Creativity of the Artist's Union of the Russian Federation "Goriatchiy Klutch " near Novorossiysk. Work in the house of creativity the beauty of the foothills, Tsemesskaya Bay, Novorossiysk, a city fanned by the glory of national history, always highlighted his work in the reporting exhibition of the house of creativity. He was a big man, with two sketchbooks, and he create several well-written art canvases every day. By the way, canvases were always primed only by myself.

V.P. Dobrolyubov spoke with inspiration and vividly about Talashkino,- the estate of Princess M. K. Tenisheva, an educated patron of the arts, an outstanding artist, the owner of an invaluable collection of paintings, icons, folk art items, ancient utensils and jewelry, located near Smolensk. She later donated this collection to Smolensk along with the two-story building of the Russian antique Museum.

At the beginning of the century, artists from the peasants - wood carvers, embroiderers, lace makers - created wonderful works of art in Talashkino.

The artist himself deeply perceived and studied the work of masters of art in pre-revolutionary Russia, such as V. Vasnetsov, M. Vrubel, M. Nesterov, E. 
Polenov, A. Golovin, M. Yakunchikova, K. Korovin, V. Serov, I. Repin, A. Prakhov, V. Polenov, I. Grabar... A rare constellation of names! This was a genuine folk layer of culture. Away from the centers, outside of profits and calculations, great, good, and beautiful things are happening. This is how I remember Talashkino, " the artist wrote.

The artist himself attached great importance to museums, the preservation of their collections of works of art, and the technique and technology of various types of painting. He especially advocated a careful attitude to folk art and its traditions, never tired of pointing out the great significance of all these values of Russian lands. As the he said, the world history of art shows that no one who had a creative mind was forgotten.

In the same statement Dobrolyubov V.P. rebelled against the phrase "commercial art", because the essence of art is the expression of Beauty. Even in early childhood, a person must be taught to create, because life itself shows that everything connected with creativity survives; scientific discoveries live, and thought lives indestructibly. So, let's learn to direct all our thoughts to the Beautiful. And the Beautiful is the art of the peoples of the world.

Dobrolyubov V.P. was a born muralist. He created numerous canvases, sometimes reaching a length of several meters. There are many of his canvases that are considered to be easel art, although in fact they are sketches of monumental compositions. Taking care first of all of those to whom the works of art are intended, the master demanded from the artist a deep education, the utmost expressiveness, the use of such artistic materials that would ensure the preservation of compositions for as long as possible.

Until the end of his life, the artist struggled with ignorance, human disunity, vulgarity. And he considered art to be the main antidote against them. Having lived a short life, he bitterly stated: "Little knowledge. Little art. There are few principles in life that can lead to a Golden age of unity. And yet the artist believed that the time will come when the knowledge, culture, art are for most people a necessity when the ineradicable human need will become pure prayer of the spirit - creativity for good.

Dobrolyubov V.P. idolized N.K. Roerich, and always repeated his words "the values of great art pass victoriously through all the storms of earthly upheavals". The artist died on February 24, 1975, having lived only 54 years, of which 7 years, from 1939 to 1945 , he defended his Homeland in the ranks of the Red Army with the rank of senior Sergeant. The artist left behind a huge creative legacy. Dobrolyubov V.P. was buried at the Rogozhskiy cemetery in Moscow.

\section{REFERENCES}

1. Exhibition "Artists whose name is associated with the village of Peski" Kuznetsky most 11, participation in the works "Staraya Ladoga". 1969 K. m., 60x70cm, "still Life in memory of Yuri Gagarin". 1970, H. M., 140x160 cm, " Dawn. Still life". 1970, Kh. m., 140x160 cm exhibition Catalog "Sands" p. 2, p. 74, Union of artists of the USSR, Union of artists of the RSFSR, MOSH RSFSR. Ed. "Soviet artist", 1989

2. Personal exhibition in "House of the Sculptor" Spasonalivkovskiy per. 5. participation in the main works created during the period 1939 - 1975, 2001. Catalog publishing house "Trhnvm", 2003.

3. Exhibition "70 years of MOSH" Moscow, Central Exibition Hall "Manege", author's works "In the temple. Yaroslavl", H. M., 100x80cm and other canvases. 2003 Mosh catalog

4. "HOUSE of ARTS. 50 years of Creativity" At Raspletina street 20. Art exibition from 09.10.2003 to 15.11.2003 main author's works for the period 1939-1975. Shukino district Council, Ministery of Culture of R.F., R.F. Academy of Fine Arts, Union of Artists of R.F., Moscow union of Artists, State Tretiakov Gallery, Pushkin State Museum of Fine Arts, "Khodynka Art Exibition hall", Levchenko str., Moscow.
5. 5. Art Exhibition "Paintings big and small", Author's canvas "Holiday" c. 0., 104x60cm, 1967g. 09-18. 12. 2004, Exhibition center MOSH Moscow, Begovaya str. 7-9, reference from 24.01.2005 signed by S. V. Goryaev.

6. 6. Art exhibition MOSH Russia "Christmas on Begovaya" Author's works "Birch grove" Kh. m., 99, 3x109, 8cm, 1967, "Apple trees are blooming" 100x80cm, 1969, 28.12.2004-09.01.2005 Exhibition center MOSH Moscow, Begovaya str. 7-9, reference from 17.01.2005 signed by S. V. Goryaev, Moscow artist Newspaper No. 12, December 2004. Catalog "Paintings big and small" p. 26, p. 34, MOSCH publishing house of Russia 2005

7. 7. Dobrolyubov P. V. House of Arts. The history of the MIPIDI. "Artist Dobrolyubov Vladimir Petrovich. Creative heritage". Edition of ARTS, artists Union of Russia. M., 2006

8. 8. All-Russian art exhibition "Art today". Moscow, Central exhibition hall "Manege" 2007 Catalog. Publishing house of the Russian Federation. M., 2007

9. 9. Catalog of Moscow painters Moscow Union of artists Publishing house, Moscow, 2012 
Петр Владимирович Добролюбов

Академик изящных искусств (ТСMCF)

художник

Московский союз художников,

Союз художников РФ

Член ревизионной комиссии МОСХ РФ

член Творческого союза художников,

Московского союза художников,

Союза художников России,

Объединения Московских скульпторов

e-mail: peterdobrolioubov@gmail.com

Россия, Москва.

ORCID 0000-0003-0709-3265

DOI: 10.36340/2071-6818-2020-16-4-113-132

\section{ЖИВОПИСЬ КАК МОЛИТВА ДУХА}

\section{Аннотация:}

Статья посвящена творчеству русского живописца Добролюбова Владимира Петровича, которому в 2020 году исполняется сто лет со дня рождения. Особое внимание уделяется изложению его идеалов, вдохновивших художника на создание замечательных живописных полотен, запечатлевших окружающий мир, ландшафты и пейзажи, городскую среду, памятники древнерусской архитектуры, убранство и интерьеры древнейших храмов от Москвы до Ярославля, Переславля Залесского, Старой Ладоги. От Русского Севера до Крымских гор и Цемеской бухты.

Владимир Петрович Добролюбов (05.07.192024.02.1975) -ученик И.И. Машкова, Н.П. Крымова, Г.Г. Ряжского, К.Ф. Юона, В.В. Крайнёва, П.И. Котова, В.И. Финогеева, К.Г. Дорохова.

Добролюбов В.П., ветеран Великой Отечественной войны, 75-летие Победы в которой мы отмечаем в нынешнем году.

Автор анализирует живопись В.П. Добролюбова - природного колориста, самородка, художника, философа и гражданина своей страны. Его мысли о живописном искусстве, основанном на красоте и традициях русской школы иконописи, явились фундаментом, духовной платформой для всего его живописного творчества, созданного в короткий период жизни.

Авторские живописные произведения Добролюбова В.П. представляют заслуженный интерес для искусствознания и вносят достойный, значительный вклад в него не только высокой оценкой их колористики, цветового пятна и лирического облика, но и как часть истории отечественной живописи и, в частности, московской школы живописи 30-60-х годов XX века, представителем которой он являлся. Заслуживает внимания также его понимание искусства, его творческий живописный, своеобразный, авторский почерк и также удивительное видение колорита и цвета - собственное, индивидуальное. Так же н, как и трактование личного восприятия, отношение и осмысление фундаментальных основ реализма в отечественном и мировом изобразительном искусстве, выраженное и утверждённое в собственном, никем не повторённом, колористическом живописном языке.

Добролюбов В.П. рассматривал иконопись, русскую икону как изобразительное искусство, которое, следуя традиции византийских мастеров иконописи, бесспорно являет собой сердцевину, душу художественного творческого процесса и особенно ярко выражено в работах таких иконописцев, как Андрей Рублёв, Феофан Грек, во Владимиро-Суздальской, Московской, Ярославской и других школах иконописи как объективная реальность мира духовных образов в своём собственном творчестве.

Художественное творчество, по его мысли, как представителя московской школы живописи, является не отвлеченным поиском и самовыражением убеждений и идей художника, а результатом глубинного, божественного преображения души, её пути к истине и к основам реалистического искусства через мироощущение художественных образов.

Высоко оценивая русскую иконопись XIV-XVII веков, привнесённую в Россию из Византии, Добролю- 
бов В.П. считал русскую школу иконописи основным, непревзойдённым, нетленным фундаментом и шедевром отечественного изобразительно искусства.

Везде и всюду в своих воспоминаниях, в своём понимании основ искусства художник отказывается от понятия копирования изображения, и икона для него представляет собой как бы условный исторический символ, указывающий на духовный образ прошлых веков. Художественный образ рождается в душе живописца и, конечно, существует вне иконописи, но затем может возникнуть в сознании других людей, созерцающих холсты мастера, в которых образ вселенского мироздания и красоты вселенной закодирован, если хотите, - зашифрован, в самих глубинных образах русской иконописи. Поэтому сама икона, её образ и композиция, как созданное однажды в глубине прошлых веков художественное произведение, олицетворяется в сознании автора как посланная с небес благодать и вдохновение.

Добролюбов В.П. подтверждает эстетическую и духовную платформу, созданную для любого человека. Поэтому русские иконы, созданные как духовно и ху-

В 2020 году исполняется сто лет со дня рождения замечательного московского живописца Добролюбова Владимира Петровича (05.07.192024.02.1975) - ученика И.И. Машкова, Н.П. Крымова, Г.Г. Ряжского, К.Ф. Юона, В.В. Крайнёва, П.И. Котова, В.И. Финогеева, К.Г. Дорохова. Добролюбов В.П., ветерана Великой Отечественной войны, 75-летие Победы в которой мы отмечаем в нынешнем году.

Добролюбов В.П. родился в Москве, Июня 24го числа по старому стилю, в 12 часов ночи 5 июля 1920 г. по новому стилю в доме № 22 на Яблонном переулке, в семье офицера Лейб-Гвардии Санкт-Петербургского Короля Фридриха-Вильгельма III полка Добролюбова Петра Григорьевича и Добролюбовой (Морозниковой) Александры Павловны.

Расцвет изобразительного искусства является символом расцвета культуры народа в любой стране. В разлагающейся стране, где сносят

Блок А. Дневник. М., 1989. С. 50 дожественно совершенные, самодостаточные произведения отечественной культуры, неразрывно связаны с общим процессом отечественной истории искусств своей способностью свидетельствовать о высочайшем её уровне в иерархии мирового искусства.

Для живописца Добролюбова русская иконопись является неотделимой частью его духовной платформы и произведений его живописи, и храмовое искусство в содружестве с древнерусской архитектурой, с интерьерами храмов и их убранством, так же как таинство богослужения, крещения, венчания и отпевания, и являются самым существенным основанием, бытием, самим художественным образом всего его творчества и теперь, в 2020 году. Сегодня, по прошествии 45 лет со дня его смерти в 1975 году, его художественные живописные авторские произведения так же прекрасны и проникновенны.

Ключевые слова: русское и советское изобразительное искусство XIX-XX веков, древнерусская икона, иконопись Византии, московская школа живописи, визуальный арт-объект, художественный образ, изобразительное искусство, символ, реализм.

В искусстве Земля подражает Небу.

А. Блок

и предают забвению памятники истории прошлых столетий, расцвет и культура этого народа будут преданы забвению так же.

Иногда искусство становится лишь отвлечённой роскошью, лишь для избранных. Когда же страна находится в полной духовной силе, то само как таковое искусство становится истинной культурной почвой, базисом, интеллектуальным фундаментом для своего народа, питает его соками земли своего отечества, оставаясь неразрывно связанным с историей искусства, созданного прошлыми поколениями далёких предшествующих эпох.

Представим себе историю человечества без этих сокровищ великого искусства и его непревзойдённой красоты и удивительной гармонии. Мы найдём то, что целые эпохи останутся без всякого значения, лишённые души и величия искусства. Без выявления духовной красоты мы останемся среди безобразия опустошительного неведения и невежества. Когда мы говорим, что красота, искусство, творчество есть жизнь, мы тем самым говорим о грядущей жизни для лю- 


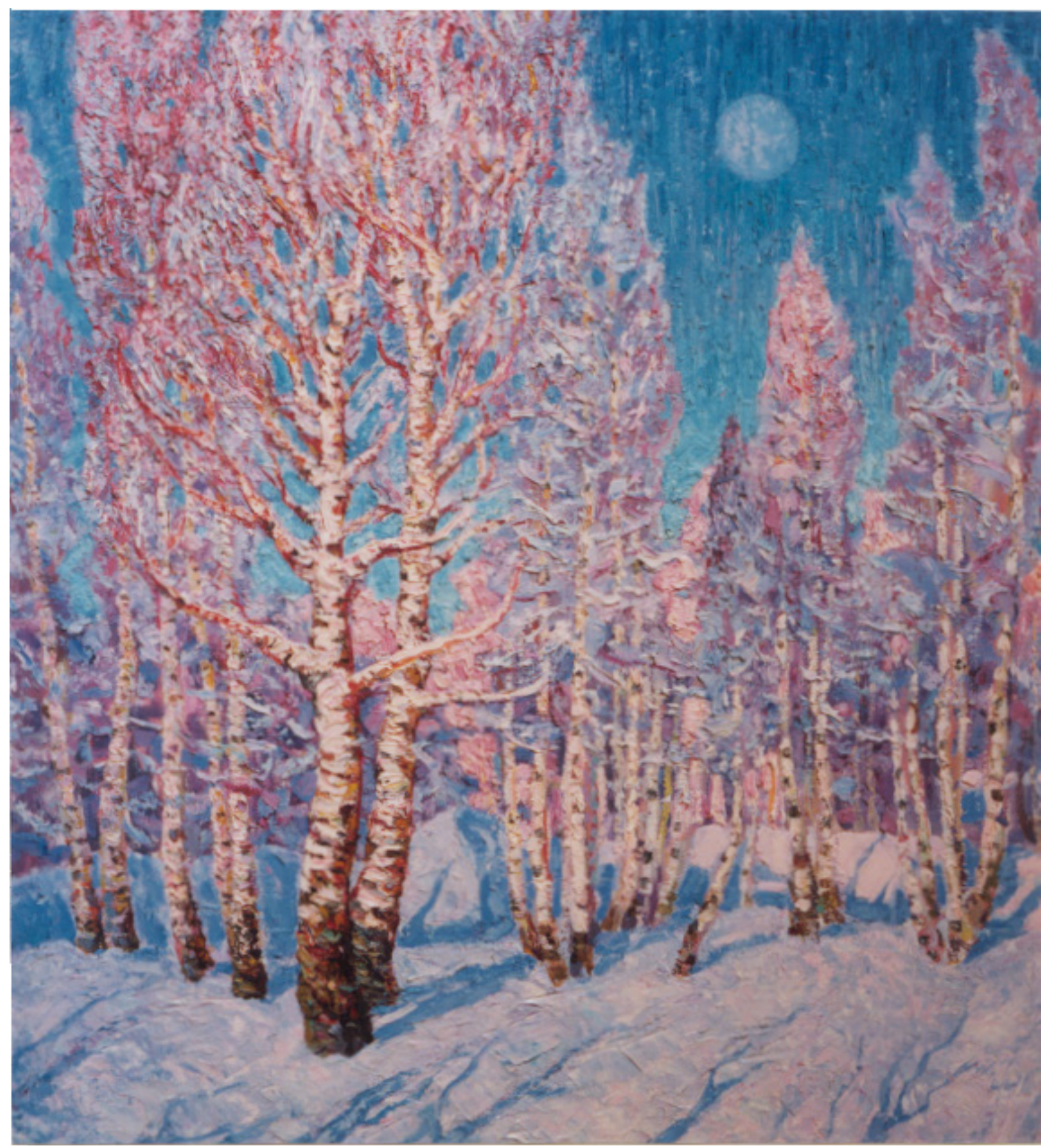

Зима. 1969

дей. Всё, что сделано для истинного творчества, для искусства, уже есть подвиг человека, созидателя. Так высоко оценивал роль искусства и сам живописец в своём творчестве. Он считал, что именно искусство приближает людей к постижению сути вещей, к пониманию истинной красоты и добра, величия мироздания и, следовательно, в жизни всего человечества значение искусства, мастеров, создающих его, просто неоценимо.
В.П. Добролюбов видел глубинный смысл искусства в том, что именно искусству дано поддержать духовную суть любого человека и помочь ему в дни невзгод и тяжелейших испытаний подняться с колен. Сила знания и глубина искусства не роскошь узкой группы людей. Познание мироздания и созидание искусства есть подвиг человека-художника, будь то живописец, скульптор или архитектор. Это молитва искусству и подвиг духа являют миру подлинные художественные шедевры разных эпох и народов. Так как эта мо- 
литва искусству, сила духа созидателя произведения наиболее необходима, когда художник стоит наедине с самим собой у холста и мольберта, как земное существо, вдохновленное божественной силой окружающего нас мира, и поэтому нуждается в твердой опоре. Сам художник должен всегда искать мудрое решение.

И там, где тверже духовная и земная опора, только там дух созидания зажжётся необычайно проникновенно. Живописец снова и снова повторяет: творчество как всеобъемлющая субстанция - это кристально чистая молитва духа. А подлинное искусство и является сердцем любого народа и любого этноса.

Познание окружающего мира, божественной первозданной природы - это и есть народный разум. Только исключительно своим добрым, умиротворённым сердцем и врождённой мудростью могут объединиться и понять друг друга, и пойти навстречу друг другу народы мира сего. А если этого нет, то происходит одичание всего земного человечества.

Добролюбов В.П. не стеснялся учиться на протяжении всей жизни. Выдающиеся художники, такие как И.И. Машков, Н.П. Крымов, Г.Г. Ряжский, К.Ф. Юон, В.В. Крайнёв, П.И. Котов, В.И. Финогеев, К.Г. Дорохов, - учителя живописца Добролюбова В.П. - по призванию все были талантливыми учителями. Вся их многогранная живописная деятельность носит также педагогическую направленность. Они и просветители, и наставники, и чуткие воспитатели. Целеустремлённые, страстные в искусстве и настойчивые в деле воспитания нашей молодёжи.

С 1937 по 1940 год он учился в Художественном училище памяти 1905 года; в 1940-1947 годах служил в рядах Красной Армии. Художник участвовал в боевых действиях с Германией и Японией в звании старшего сержанта, был награждён медалями «За Пебеду над Германией», «За Победу над Японией» и другими медалями. В 1946 году Добролюбов В.П. был принят в студию им. Грекова на конкурсной основе с художниками Н. Жуковым и В. Утениным.

Творческое наследие живописца Добролюбова В.П., будь то листы дневника, авторские живописные произведения, рассказы, стихи, являют собой вдохновенный призыв к постижению искусства, к культурному строительству. Глубина и обширность знаний в соединении с жизненным и творческим опытом дали художнику бесценный материал для многих живописных произведений. В 1953 году он дебютирует в выставке художников картиной «А.М. Горький на берегу моря» (1953). С 1954 по 1960 год творческая работа в Крыму, Гурзуфе в Доме творчества им. К. Коровина и в Судаке. Вот лишь некоторые холсты: «Судак, вечер» (1954), «Гурзуф» (1955), «Ялта» (1956), «Дом творчества К. Коровина» (1956), «Осень в Крыму» (1957), «У Медведь горы» (1957), «Крым, Красный Камень» (1958), «Гурзуф» (1959), «Теплый Вечер» (1960), «Судак» (1960), «Море вечером» (1960), «Крым» (1960), «Кипарисы» (1961). Лишь только малая часть его произведений представлена в нашем журнале.

Разные по глубине, тематике, охвату, жанру, по объёму - все они пронизаны общей идеей: без искусства жизнь человека абсолютно невозможна, лишена всякого смысла и красоты. Порой художник касается, казалось бы, узкопрофессиональных вопросов: композиция, тон в живописи, пейзаж или натюрморт, методы работы над произведением, химический состав красок и т.д. Однако все они чрезвычайно важны, ибо показывают суть творческой деятельности Добролюбова В.П. как художника, мыслителя, гражданина своей родины.

Живопись Добролюбова В.П. глубоко и радостно раскрывает его отношение к творчеству художника, к законам и природе созидания в творческом процессе. Не знающий прошлого, утверждал художник, не может думать о будущем. Вот почему Добролюбов В.П. сам посвятил своё творчество сюжетам с древнерусской архитектурой, иконам, фрескам, мозаикам в интерьерах могучих исполинов храмов, которые передают на холсте чудные, небесные, светоносные краски. Наконец мы прозрели: из наших временно забытых кладовых добыли мы ещё одно дивное чудное сокровище.

Познание икон будет верным талисманом в пути к прочим нашим древним сокровищам и красотам, так близким исканиям будущей жизни. И всё творчество живописца Добролюбова В.П. есть именно живое и весьма убедительное доказательство того, что древнерусское искусство не просто красивый музейный экспонат или изжившая себя форма художественного творчества, а именно само божественное мироздание, окружающее всех нас, всё человечество. Сам художник, осознав глубинный смысл иконописи, смог увидеть главное в древнерусском искусстве, 


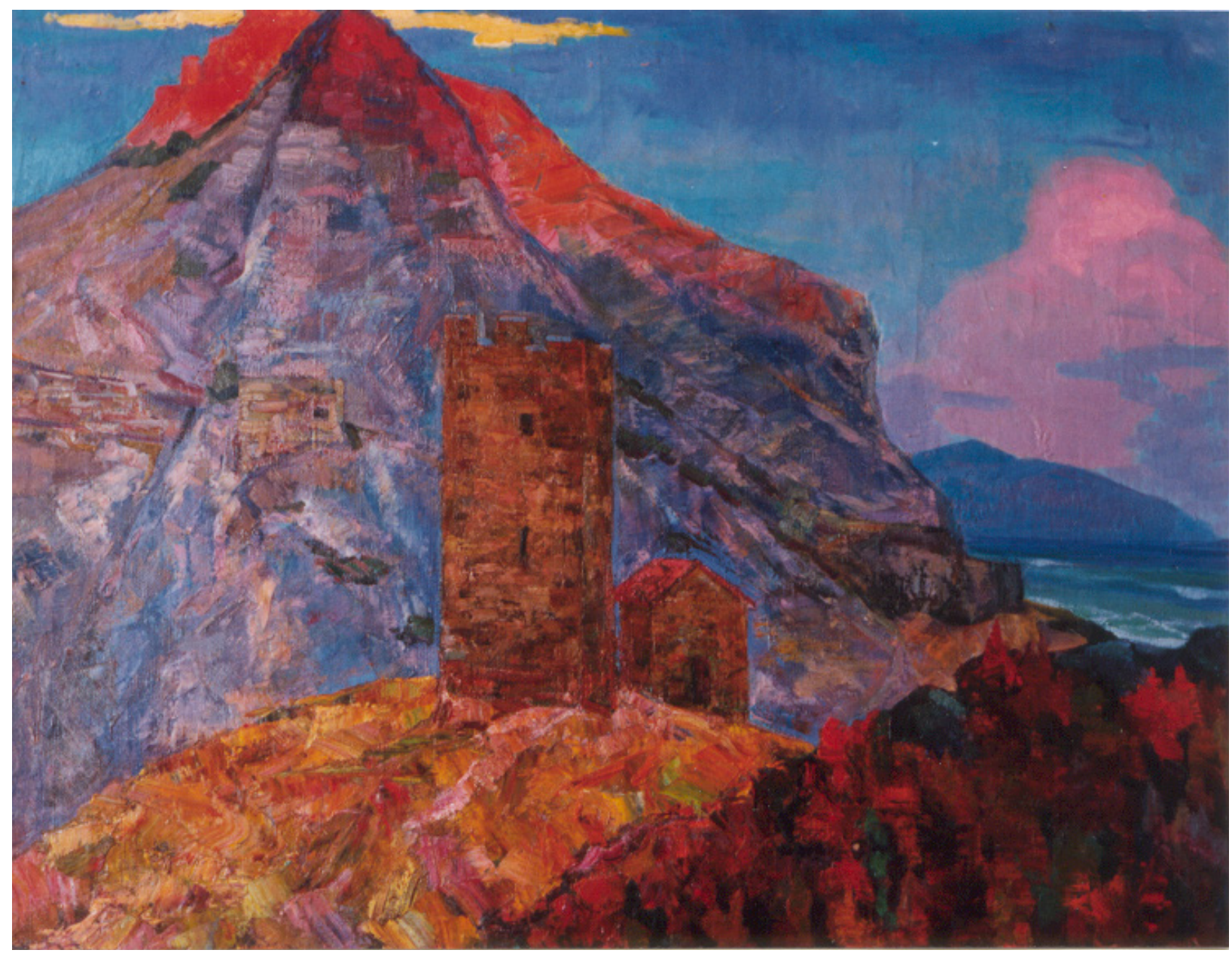

Судак. 1963

по-своему продолжил его традиции в своём живописном творчестве.

В 1963 году Добролюбов В.П. написал одну из лучших своих картин «Верхняя Масловка. Вид из окна» (1963). Это даже не просто натюрморт, а уникальная по форме, мастерству и красоте эпохальная полотно-картина, в которой соединились научная достоверность с прозрением ясновидца. Дух захватывает, когда вместе с автором путешествуешь во времени и наконец оказываешься в глубинах Городка художников на Верхней Масловке. Живописец ищет единый корень своего творчества в единстве с мировым искусством живописи и находит его в непревзойдённых шедеврах прошлого.

С 1964 года художник работает в Доме творчества в Тарусе. Его холсты полны лиризмом и очарованим родной природы, такие как «Звезды зажглись» (1964), «Вечером у Оки» (1964), «Таруса» (1964), «Закат» (1964). В 1968 году художник принят в живописную секцию СХ СССР Московской организации союза художников. В 1969 году участвует в выставке «Памятники истории и культуры нашей родины в произведениях московских художников» МОСХ РСФСР с такими работами, как «Суздаль» (1965), «Никольская деревянная церковь из села Глотова» (1966), «Интерьер церкви Воскресения в Ростове Великом» (1967), «Осень в Ростове» (1967), «Западный фасад храма Покрова на Нерли. Рассвет» (1968), «Храм Бориса и Глеба в Кидекше» (1968), «Весенний вечер. Храм Вознесения в Коломенском» (1968).

Стыдно для нашего времени, что в древности не существовало ни одного предмета быта без истинной работы автора, человека, мастера, художника. Невозможно даже сравнивать народный обиход нашей современной жизни с тем, что так настойчиво стремились иметь около себя поколения предшественников из тех же мест. К любым прекрасным вещам приложите идею, свои знания, свой опыт, палитру и кисти, и оно не нарушит общего впечатления от его живописи. Оно принесёт с собою ноту созидания и покоя, глубины познания окружающего нас мира и благородства самого творческого процесса.

Углубляясь в века, Добролюбов В.П. намечает главные вехи радости в создании своего живописного искусства. Основным является тема 
русского искусства, которое всегда восхищало мастера своей неповторимостью, образностью и жизнеспособностью. Всё, что приходило в русское искусство извне, растворялось, становилось органичным лишь тогда, когда отвечало духу, характеру, взглядам, привычкам народа, его национальным особенностям.

Наша отечественная русская культура никогда не чуралась культуры соседних и даже дальних стран, но всегда при этом оставалась верной своим историческим фундаментальным традициям. Поэт живописи, историк, философ, художник и искусствовед, Добролюбов В.П. рассматривал искусство в единстве и лаконизме всех известных жанров, в общем художественном укладе на протяжении всей своей земной творческой жизни.

Его пейзажи - это песнь о красоте земли русской, её очаровании, которая для живописца Добролюбова В.П. входит в его полотна вполне осязательным явлением. Многие из этих увиденных пейзажей переносились на его холсты. Вспомним лишь некоторые: «Старая Ладога. Север» (1969), «Труворов крест» (1970), «Юрьев Польской» (1970), «На рассвете» (1970), «Небесный зов» (1970).

С 1969 года он плодотворно пишет живописные холсты с нетронутой природой поселка «Советский Художник» в Песках и его окрестностей. Природа там всё так же восхитительна, те же голубые небесные волны Москвы-реки, вишнёвые облака над ней, те же бездны акаций, пионов, тюльпанов в садах у соседей художников. Автор может творить только тогда, когда его сердце отдано людям и душа открыта живым впечатлениям, красоте мироздания. Работы этого периода «Золотая осень» 1972 г., «Яблонька цветёт» (1972), «Натюрморт с книгой» (1973), «Конев Бор» (1973), «яблони в саду» (1974), «Ночь, Пески» (1974) и многие другие. С горечью говоря о деградации современного искусства за рубежом, утрате национальных традиций, художник выражал не меньшую тревогу в связи с упадком в России художественной культуры, эстетических потребностей народа.

Добролюбов В.П. с детства проникся любовью к декоративно-прикладному искусству, пониманием его огромных возможностей, недаром в течение многих лет он писал свои натюрморты с народными промыслами. Этому посвящена его фундаментальная картина «Карусель». На карусели изображены так горячо любимые им образы народных промыслов. Как художник, работавший во многих фильмах Александра Роу, он возражал против несправедливого отделения так называемой «художественной промышленности» от искусства и причисления к чему-то второстепенному.

Он считал, что не существует второстепенных областей приложения творческих сил - есть плохие художники. Большой мастер создаёт высокое произведение искусства из любого материала и любыми техническими средствами, - повторял Добролюбов В.П., следуя своему постоянному девизу: «Искусство едино».

Конечно же моральный облик, поведение в обществе художника-творца непосредственно влияют на результаты его деятельности.

Взаимоотношениям «молодых» и «старых» художников в Городке Художников на Верхней Масловке, где он жил, посвящена часть его воспоминаний, там же он продолжает тему этики художника, «художественных разноверцев» и выражает твёрдую убеждённость в необходимости единения всех творческих сил страны в деле всеобъемлющего культурного строительства.

В 1969-1970 годах состоялась творческая командировка в Старую Ладогу, где было написано большое количество произведений, работа в Доме творчества и участие в отчётной выставке Дома творчества СX СССР.

В 1970 году МОСХ РСФСР награждает Добролюбова В.П. дипломом за участие в 5-й Выставке произведений художников-ветеранов Великой Отечественной войны, посвященной 25-летию победы над фашистской Германией.

Многовековой опыт указывает нам, что искусство и знание расцветали там, где сверху они признавались величайшими стимулами жизни. «Там, где главы государства, где владыки церкви и все руководители жизни сходились в стремлении к прекрасному, только там и происходил ренессанс, - то возрождение, о котором теперь пишут такие восхитительные книги наши искусствоведы», - говорил живописец, продолжая всё ту же тему о всех видах искусства и архитектуры, без которых личность человека лишена перспектив его подлинного развития и движения вперёд к вершинам миропознания.

Добролюбов В.П. был убеждённым реалистом-романтиком, ибо считал высочайшей задачей искусства отображение жизни как таковой, во всей её глубине, многогранности. «Истинный 


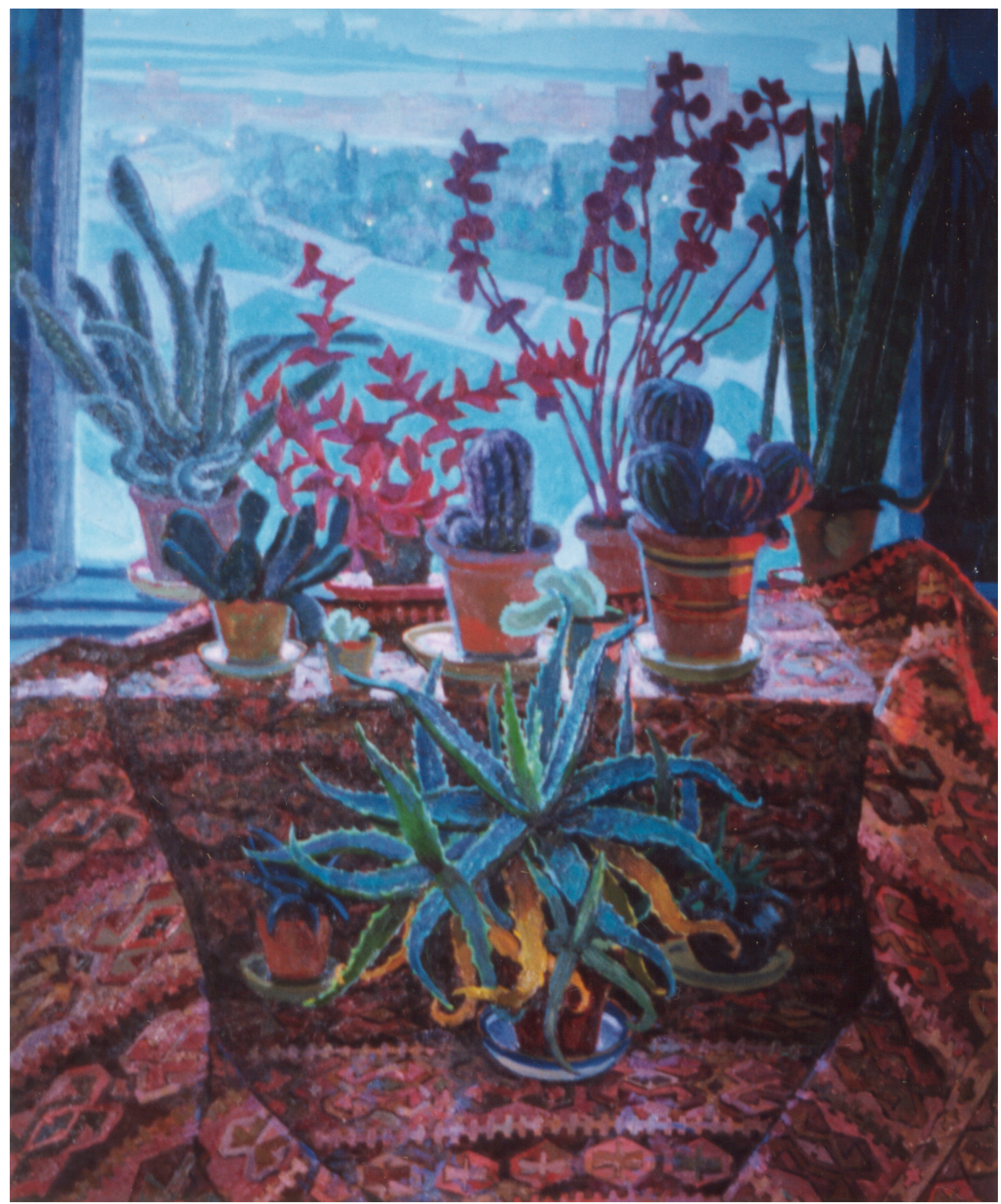

Верхняя Масловка. Вид из окна. 1963

реализм отображает сущность вещей. Для подлинного творчества реализм есть исходное восхождение. Сколько раз самый наиреальнейший кусок природы назывался небывальщиной! Уж не говорить о красках. Эти сочетания цветовой палитры, быстро, a la prima и этюдно взятые из природы, объявлялись невозможными, а формы, запечатленные с натуры, считались почему-то выдумкой».
Глубоко реалистический подход к изображаемому сюжету - основная черта творчества Добролюбова В.П., в котором соединились яркая авторская самобытность с жизненной достоверностью. Неудивительно поэтому, что его картины «У Савино-Сторожевского монастыря» (1961), «Утро в Переславле Залесском» (1963) вдохновили режиссера А. Роу на создание волшебных детских фильмов на Киностудии юношеских филь- 
мов имени А.М. Горького, например такого как «Огонь, вода и медные трубы» (1967), где сам Александр Роу уговорил живописца Добролюбова В.П. сыграть роль царского виночерпия в этой картине.

Художник считал, что все мы способны видеть красоту окружающего мира, сотворённую небесными силами. Это и есть загадочное «небесное зодчество». Так живописец называл облака, которые всегда приносили ему большую эстетическую радость. Он писал: «Все люди определённо делятся на два типа. Одни умеют радоваться небесному зодчеству, а для других оно молчит, или, вернее, сердца их безмолвствуют и молчат. И лишь дети безраздельно умеют радоваться облакам и возвышают своё воображение в своём юном возрасте. А ведь воображение наше - лишь следствие наблюдательности. И каждому от первых дней его уже предлагается неописуемая по красоте своей небесная живопись. Люди должны любить прекрасное в окружающем мире, и эту любовь надо постоянно развивать». Так считал Владимир Петрович Добролюбов.

С 1971 по 1975 год художник часто работает в Доме творчества СХ РФ «Горячий Ключ» под Новороссийском. Работа в доме творчества, красота предгорья, Цемесской бухты, Новоросийска - города, овеянного славой отечественной истории, всегда выделяли его работы в отчётной выставке Дома творчества. Могучего роста, с двумя этюдниками за день он писал несколько проникновенных работ. Холсты всегда грунтовал только сам.

Вдохновенно, ярко говорил Добролюбов В.П. о Талашкине - расположенном близ Смоленска имении княгини М.К. Тенишевой, образованной меценатки, незаурядного художника, обладательницы бесценной коллекции картин, икон, предметов народного творчества, старинной утвари и украшений. Эту коллекцию она передала позже в дар Смоленску вместе с двухэтажным зданием музея «Русская старина».

В начале века художники из крестьян - резчики по дереву, вышивальщицы, кружевницы - создавали в Талашкине замечательные произведения искусства.

Сам художник глубоко воспринял и изучил творчество мастеров живописи России дореволюционной, таких как В. Васнецов, М. Врубель, М. Нестеров, Е. Поленова, А. Головин, М. Якунчикова, К. Коровин, В. Серов, И. Репин, А. Прахов,
В. Поленов, И. Грабарь... Редкое созвездие имен! Это был подлинный народный пласт культуры. «В стороне от центров, вне барышей и расчётов творится большое, хорошее, красивое. Так вспоминается Талашкино», - писал художник.

Огромное значение придавал живописец музеям, сохранности их фондов художественных произведений, технике и технологии различных видов живописи. Особенно он ратовал за бережное отношение к народному искусству, его традициям, не уставая указывать на великое значение всех этих ценностей российских земель. Как говорил живописец, «всемирная история искусств показывает, что ни один человек, имевший творческий ум, не был забыт».

В этом же утверждении Добролюбов В.П. восстаёт против словосочетания «коммерческое искусство», ибо суть искусства - выражение Прекрасного. Уже в раннем детстве человек должен быть научен творчеству, ибо сама жизнь показывает, что всё, связанное с творчеством, выживает; живут научные открытия и неистребимо живет мысль. Итак, научимся направлять все наши мысли к Прекрасному. А Прекрасное это и есть искусство народов мира.

Добролюбов В.П. был прирождённым монументалистом. Он создал многочисленные холсты, порой достигающие в длину нескольких метров. Существует немало его картин, которые принято рассматривать как станковые, хотя на самом деле они являются эскизами монументальных композиций. Заботясь прежде всего о тех, кому предназначены произведения искусства, мастер требовал от художника глубокой образованности, предельной выразительности, применения таких художественных материалов, которые обеспечивали бы сохранность композиций в течение максимально длительного времени.

До конца жизни художник боролся с невежеством, людской разобщённостью, пошлостью. И главным противоядием против них считал Искусство. Прожив короткую жизнь, он с горечью констатировал: «Мало знания. Мало искусства. В жизни мало тех устоев, которые единственно могут привести к золотому веку единства». И все-таки живописец верил, что наступит время, когда знание, культура, искусство будут для подавляющего большинства людей жизненной необходимостью, когда неистребимой потребностью человека станет чистая молитва духа - творчество во имя Добра. 


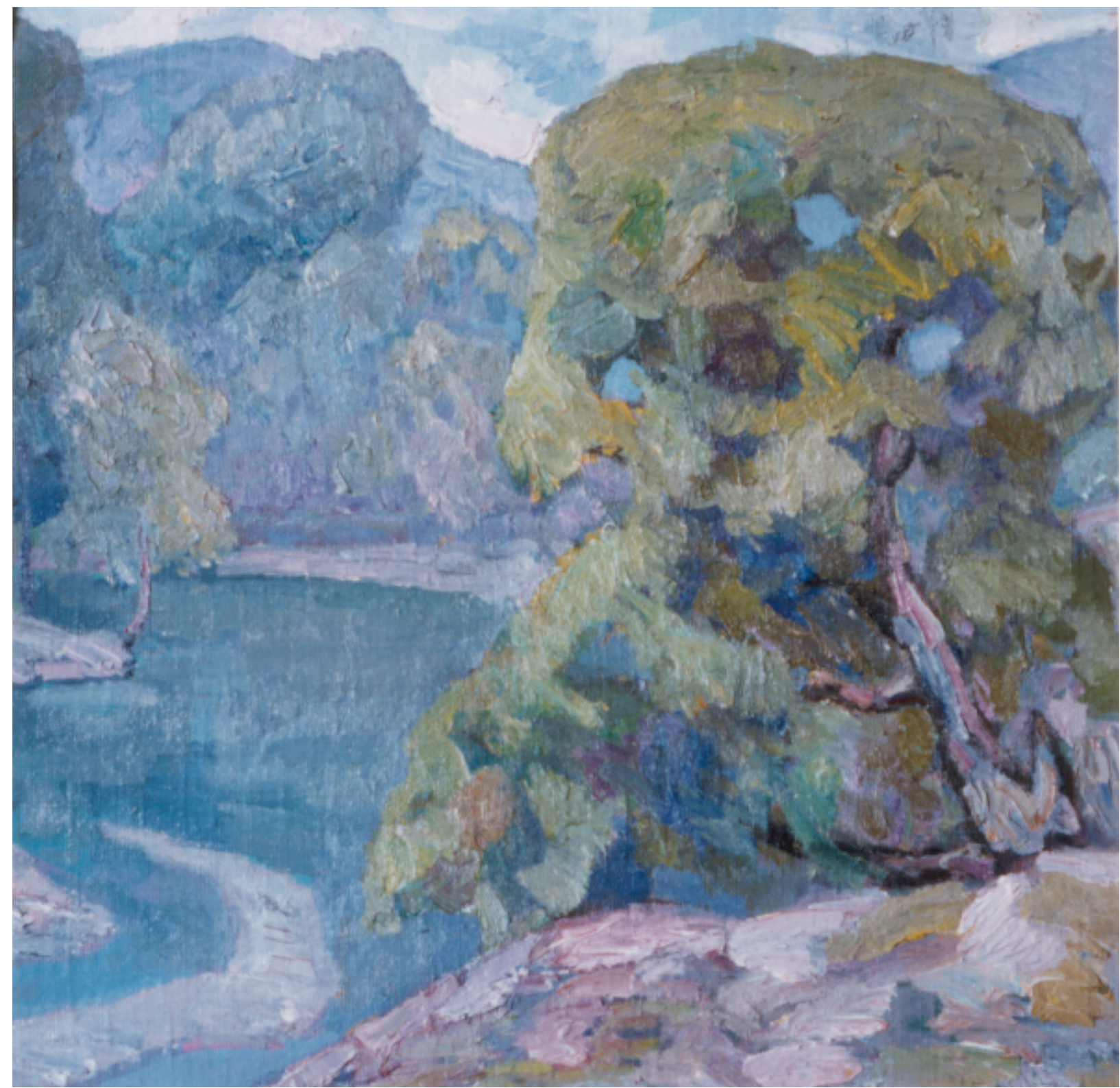

Рядом с Новороссийском 1970

Добролюбов В.П. боготворил Н.К. Рериха и всегда повторял его слова: «Ценности великого искусства победоносно проходят через все бури земных потрясений». Живописец скончался 24 февраля 1975 года, прожив всего 54 года, из ко- торых 6 лет, с 1939 по 1945, он защищал свою Родину в рядах РККА в звании старшего сержанта. Художник оставил после себя гигантское творческое наследие. Похоронен Добролюбов В.П. на Рогожском кладбище в Москве.

\section{БИБЛИОГРАФИЯ}

1. Выставка «Художники, чьё имя связано с посёлком Пески», Кузнецкий мост, 11, участие работами «Старая Ладога». 1969, к.м., 60×70 см; «Натюрморт памяти Юрия Гагарина». 1970, х.м., 140×160 см; «Рассвет. Натюрморт». 1970, х.м., 140×160 см. Каталог выставки «Пески» / Союз художников СССР, Союз художников РСФСР, МОСХ РСФСР. - Изд. «Советский художник», 1989. - С. 2, 74.
2. Персональная выставка «Дом Скульптора», Спасоналивковский пер., д. 5, участие основными работами, созданными за 1939-1975 гг., 2001 г. Каталог. - Изд. «ТРХнВМ», 2003.

3. Выставка «70 лет МOCX». Москва, Манеж, авторские произведения «В храме. Ярославль», х.м., $100 x 80$ см и другие холсты. 2003 г. Каталог MOCX. 
4. Выставка с 09.10.2003 по 15.11.2003, основные авторские произведения за период 1939-1975 гг. УПРАВА РАЙОНА ЩУКИНО, МИНИСТЕРСТВО КУЛЬТУРЫ РОССИИ, РОССИЙСКАЯ АКАДЕМИЯ ХУДОЖЕСТВ, СОЮЗ ХУДОЖНИКОВ РОССИИ, МОСКОВСКИЙ СОЮЗ ХУДОЖНИКОВ, ГОСУДАРСТВЕННАЯ ТРЕТЬЯКОВСКАЯ ГАЛЕРЕЯ, ГОСУДАРСТВЕННЫЙ МУЗЕЙ ИЗОБРАЗИТЕЛЬНЫХ ИСКУССТВ ИМЕНИ А.С. ПУШКИНА, ВЫСТАВОЧНЫЙ ЗАЛ «ХОДЫНКА», ВЫСТАВКА ХУДОЖЕСТВЕННЫХ ПРОИЗВЕДЕНИЙ «ДОМ ИСКУССТВ. 50 ЛЕТ ТВОРЧЕСТВА» НА УЛИЦЕ РАСПЛЕТИНА, 20.

5. Выставка «Картины большие и маленькие», авторская работа «Праздник» Х.м., 104х60 см, 1967 г. 09-18.12.2004, Выставочный центр МОСХ, г. Москва, Беговая ул. д. 7-9, справка от 24.01.2005, подпись С.В. Горяев.
6. Выставка МОСХ России «Рождество на Беговой», авторские работы «Березовая роща» х.м., 99,3х109,8 см, 1967 г., «Яблони цветут», 100x80см, 1969, 28.12.2004- 09.01.2005, Выставочный центр МОСХ, г. Москва, Беговая ул., д. 7-9, справка от 17.01.2005, подпись С.В. Горяев //Газета «Московскийхудожник».№ 12. - Декабрь 2004. Каталог «Картины большие и маленькие». - Изд. МОСХ России, 2005. - С. 26, 34.

7. Добролюбов П.В. Дом Искусств. История МИПИДИ // Живописец Добролюбов Владимир Петрович. Творческое наследие / Издание РАХ, СХ РФ. - М., 2006.

8. Всероссийская выставка «Искусство сегодня». Москва, ЦВЗ «Манеж», 2007 г. Каталог. - Изд. СХ РФ. - М., 2007.

9. Каталог Московских живописцев. - М.: Изд. «Московский союз художников», 2012. 